\author{
Military Technical College \\ Kobry El-Kobbah, \\ Cairo, Egypt.
}

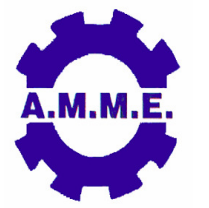

$15^{\text {th }}$ International Conference on Applied Mechanics and Mechanical Engineering.

Invited lecture

\title{
HIGH-ORDER ACCURATE SCHEMES AND LES WITH APPLICATIONS IN AERO-ACOUSTICS
}

\author{
Prof. Dr. Chris Lacor \\ Chairman Research Group Fluid Mechanics and Thermodynamics, Dept. \\ Mechanical Engineering, Vrije University in Brussels, Belgium.
}

\begin{abstract}
High-order schemes and Large Eddy Simulation (LES) are essential ingredients of Aero-acoustics solvers. In this presentation high-order spectral difference methods are introduced coupled to an efficient Lower-upper symmetric Gauss-Seidel (LUSGS) solver for time integration. The extension of the methodology to LES is discussed and several LES test cases are presented. The use of LES, Linearized Euler and acoustic analogies within a hybrid Aero-acoustics methodology is explained. Several applications illustrating the method, such as noise generation of a 3D muffler, are discussed.
\end{abstract}

